\title{
EFFECTS OF MATERNAL BLOOD LOSS ON EMBRYONIC AND PLACENTAL DEVELOPMENT IN THE RAT
}

\author{
N. W. BRUGE AND D. A. CABRAL \\ Department of Anatomy and Human Biology, The University of Western Australia, \\ Nedlands, Western Australia 6009
}

(Received 21st January 1975)

\begin{abstract}
Summary. The effects of acute loss of maternal blood on embryonic and placental development was examined in 50 rats on Days 8 or 9 of gestation. Blood was withdrawn from conscious, cannulated rats over a 1 -min period at 1.0 or $2.0 \mathrm{ml} / 100 \mathrm{~g}$ body weight. These degrees of blood loss were expected to produce a mild (about 50\%) and severe (about $80 \%$ ) reduction in uterine blood flow, respectively, for at least $15 \mathrm{~min}$. There was no evidence that loss of blood affected either fetal survival and malformation rates or fetal weights and sex ratios. The anaemia resulting from haemorrhage lasted no longer than 6 days. Placental weights were $11 \%$ higher in rats losing $2.0 \mathrm{ml}$ blood $/ 100 \mathrm{~g}$ than in controls $(P<0.05)$. It appears that the $8-$ or 9 -day rat embryo is highly resistant to the partial reduction in uterine blood flow, maternal anaemia and other possible challenges induced by maternal loss of blood at levels sufficient to affect the mothers.
\end{abstract}

\section{INTRODUCTION}

Normal embryonic and fetal development depends on an adequate maternal placental blood flow. A temporary but total restriction of the uterine circulation has been shown to cause fetal death, growth retardation and malformation in anaesthetized rats (Franklin \& Brent, 1964; Bruce, 1972a). In conscious rats these embryopathic effects are even more apparent (Bruce, 1972b). Little is known, however, of the susceptibility of the embryo to a partial restriction of the uterine circulation, an event more likely to have clinical relevance, since it is difficult to produce experimentally. Mechanical techniques, such as extra-corporeal circuits and vascular occlusion cuffs have been tried, but fetal mortality rates in control rats were greatly increased (Bruce, 1973). A more physiological challenge, maternal loss of blood, was then investigated and was found to reduce the uterine circulation consistently to very low levels (Bruce, 1973).

The present work was designed to correlate the reduction in uterine blood flow, following maternal blood loss, with the effects on subsequent embryonic development, and on placental weight since some forms of maternal anaemia 
have been reported to cause placental hypertrophy in women (Beischer $e t$ al., 1968).

\section{MATERIALS AND METHODS}

Nulliparous albino Wistar rats with a mean weight of $204 \mathrm{~g}$ at mating were used. The rats were kept in an environmentally controlled building: the mean temperature was $19^{\circ} \mathrm{C}$ (range 17 to $23^{\circ} \mathrm{C}$ ), the relative humidity was $60 \%$ (range 50 to $75 \%$ ), and the lights were kept on from 07.00 to 21.00 hours. Food and water were freely available. The rats were mated overnight and the morning spermatozoa were found in a vaginal smear was called Day 1 of gestation. Rats from this colony normally littered on the morning of Day 23.

Cannulation. All rats were chronically cannulated so that blood samples could be taken from the fully conscious animals. On the morning of Day 7 each rat was anaesthetized with $40 \mathrm{mg}$ sodium pentobarbitone $/ \mathrm{kg}$ intraperitoneally. Lignocaine hydrochloride was infused locally along each incision site. A cannula (12 cm long, $0.8 \mathrm{~mm}$ o.d. $\times 0.5 \mathrm{~mm}$ i.d.) was passed down the left carotid artery until its tip lay about $1 \mathrm{~cm}$ distal to the aortic arch. A blood sample was then taken for an initial haematocrit recording, the cannula was flushed with heparinized saline (100 i.u./ml) and tied in position. The free end of the cannula was temporarily sealed with a blunt pin and coiled beneath a small skin incision over the dorsal neck region. For subsequent access to the cannula the rat was restrained with its head in a muzzle, the suture closing the neck incision was cut and a small portion of the cannula was returned beneath the skin. Local skin infections developed in about five rats but these responded rapidly to topical antibiotics. After cannulation, and with the rat still anaesthetized, a ventral mid-line laparotomy was performed. The uterus was examined and the number and position of all conceptuses were recorded. The laparotomy was closed and the rat was allowed to recover. Rats were subsequently kept in individual cages to protect the cannulae and were left undisturbed except when bled for the experimental treatments or haematocrit measurement.

Bleeding and haematocrit readings. The experimental rats were bled on Days 8 or 9 , a time when the rat embryo appears to be particularly susceptible to a total restriction of the uterine circulation (Franklin \& Brent, 1964). The losses of blood were 1.0 or $2.0 \mathrm{ml} / 100 \mathrm{~g}$ body weight and were expected to cause moderate (about $50 \%$ ) and severe (about $80 \%$ ) reductions in the uterine circulation respectively (values extrapolated from Bruce, 1973). The blood was withdrawn steadily over a 1 -min period and the rats were then allowed to recover quietly in their cages. Blood withdrawn from rats in Group 4 (see Table 1) was collected in a syringe previously rinsed with heparinized saline $(1000$ i.u. $/ \mathrm{ml})$ and cooled to about $5^{\circ} \mathrm{G}$. One hour after bleeding the blood was rewarmed and $50 \%$ was steadily returned to the rat over a 4-min period. The remaining blood was similarly returned after a further $30 \mathrm{~min}$ had elapsed. The results from this group were compared with those from other groups to distinguish the effects of acute hypovolaemia alone from hypovolaemia and the chronic anaemia resulting from blood loss.

A micro-haematocrit estimate was always made on the blood withdrawn 
for treatment. Other micro-haematocrit readings were taken after the first three drops of blood from the cannula had been discarded. Micro-haematocrit samples were spun for $5 \mathrm{~min}$ at $12,000 \mathrm{~g}$.

The behaviour of each rat 2 min after bleeding was scored using the following index: 0 , rat prostrate with no apparent postural reflexes; 1 , posture correct but no attempt to walk; 2, would walk if encouraged; 3, active but dull; 4, behaviour normal.

Pregnancy assessment. On the morning of Day 22, the day before expected parturition, rats were killed with an overdose of sodium pentobarbitone and their uteri were examined. The number and position of all conceptuses were recorded and compared with the record made at Day 7 . Fetuses and placentae were then removed. Fetuses were classified as 'live' if reflex movements could be elicited by pressure stimuli, and such fetuses were blotted dry, weighed and examined for external malformations as described by Wilson (1965). The placental membranes and umbilical cord were removed from each placenta. The placenta was wiped dry over a plastic surface, placed in an hermetically sealed vial to prevent further moisture loss and was weighed.

Cannulation problems. About $25 \%$ of the rats mated and cannulated for the experiment developed diarrhoea, lost weight and appeared generally unhealthy within 1 week of the operation. Rats in the experimental and control groups appeared to be equally affected. Five rats died before Day 22. Post-mortem examinations revealed extensive thrombus formation and damage to the wall of the aorta near the tip of the cannula. Kidney and gut infarcts were common and none of the severely affected rats was pregnant or showed any evidence of the original implantation sites recorded on Day 7. Two cannula types had been used in the experiment; polyethylene and clear vinyl (Dural Plastics, Sydney). Since there appeared to be a difference in the results depending on the catheter type used, a more extensive trial was carried out. Nine non-pregnant rats were cannulated with clear vinyl tubing (Dural Plastics No. SV31), and eleven non-pregnant rats with polyethylene tubing (Dural Plastics, No. SP31). The rats cannulated with clear vinyl lost $1.9 \pm 2.0 \mathrm{~g}$ (S.E.M.) over the first week following the operation while the rats cannulated with polyethylene lost $28 \cdot 1 \pm 2.9 \mathrm{~g}$. The difference in weight loss, $26 \cdot 2 \mathrm{~g}$, was highly significant $(P<0 \cdot 001)$. Seven of the nine rats cannulated with clear vinyl mated within 1 week whereas only $2 / 11$ cannulated with polyethylene mated in the same time. Post-mortem examinations revealed that clear vinyl cannulae caused much less damage to the aortic wall and fewer kidney and gut infarcts than did the polyethylene cannulae. On the basis of these results all of the original rats (five from Group 1 and four, four, three and four from Groups 2, 3, 4 and 5 respectively) which had lost $>20 \mathrm{~g}$ at any stage between the time of cannulation (Day 7) and the time of Caesarean section (Day 22) were therefore excluded.

\section{RESULTS}

A total of 50 rats was included in the results (Table 1). The five rats that were not pregnant at Day 22, and the three rats that died shortly after bleeding were recorded as such but were not otherwise used to calculate mean values. 
The withdrawal of blood over a period of 1 min caused considerable changes in maternal behaviour. At the withdrawal level of $2.0 \mathrm{ml}$ blood/100 g, 3/26 rats died within 10 min of bleeding. Of the 23 rats that survived when the loss was of the order of $2.0 \mathrm{ml}$ blood $/ 100 \mathrm{~g}$, eight were given a score, $2 \mathrm{~min}$ after bleeding, of ' 0 ', seven a score of ' 1 ', seven were given ' 2 ', and one was given ' 3 '. Rats bled at the level of $1.0 \mathrm{ml} / 100 \mathrm{~g}$ were scored around ' 3 ' and the control rats showed no apparent behavioural change after a $100 \mu l$ sample

Table 1. Effects of maternal blood loss on embryonic development in rats

\begin{tabular}{|c|c|c|c|c|c|}
\hline & \multicolumn{5}{|c|}{ Group } \\
\hline & 1 & 2 & 3 & 4 & 5 \\
\hline Blood loss $(\mathrm{ml} / 100 \mathrm{~g})$ & Control & 1 & 1 & $\begin{array}{c}2 \\
\text { (replaced) }\end{array}$ & 2 \\
\hline Day of bleeding & - & 8 & 9 & 9 & 9 \\
\hline No. of rats not pregnant on Day 22 & 2 & 0 & 0 & 1 & 2 \\
\hline No. of rats pregnant on Day 22 & 9 & 7 & 6 & 7 & 13 \\
\hline Weight at mating $(\mathrm{g})$ & $\begin{array}{l}202 \\
\pm 6\end{array}$ & $\begin{array}{r}205 \\
\pm 10\end{array}$ & $\begin{array}{r}203 \\
\pm 8\end{array}$ & $\begin{array}{l}196 \\
\pm 7\end{array}$ & $\begin{array}{r}210 \\
\pm 7\end{array}$ \\
\hline Weight at Day $22(\mathrm{~g})$ & $\begin{array}{r}263 \\
\pm 14\end{array}$ & $\begin{array}{r}275 \\
\pm 15\end{array}$ & $\begin{array}{r}240 \\
\pm 16\end{array}$ & $\begin{array}{r}228 \\
\pm 17\end{array}$ & $\begin{array}{r}289 \\
\pm 12\end{array}$ \\
\hline Weight increase during pregnancy (g) & $\begin{array}{r}61 \\
\pm 11\end{array}$ & $\begin{array}{r}70 \\
\pm 6\end{array}$ & $\begin{array}{r}37 \\
\pm 10\end{array}$ & $\begin{array}{r}32 \\
\pm 12\end{array}$ & $\begin{array}{r}79 \\
\pm 8\end{array}$ \\
\hline Deaths after bleeding & 0 & 0 & 0 & 1 & 2 \\
\hline Behaviour after bleeding $f$ & $\begin{array}{r}4 \\
\pm 0\end{array}$ & $\begin{array}{l}3.5^{* *} \\
\pm 0.2\end{array}$ & $\begin{array}{l}2.7 * * \\
\pm 0.4\end{array}$ & $\begin{aligned} & 1.0 * * * \\
\pm & 0.4\end{aligned}$ & $\begin{aligned} & 1.6^{* * * *} \\
\pm & 0.4\end{aligned}$ \\
\hline No. of implantations at Day 7 & $\begin{array}{c}12.7 \\
\pm 0.47\end{array}$ & $\begin{array}{c}11 \cdot 3 \\
\pm 0.97\end{array}$ & $\begin{array}{c}10.7 \\
\pm 0.71\end{array}$ & $\begin{array}{c}11.9 \\
\pm 0.74\end{array}$ & $\begin{array}{c}12 \cdot 4 \\
\pm 0.92\end{array}$ \\
\hline No. of live fetuses at Day 22 & $\begin{array}{c}11.8 \\
\pm 0.43\end{array}$ & $\begin{array}{c}10 \cdot 3 \\
\pm 1.15\end{array}$ & $\begin{array}{c}8.6 \\
+1.58\end{array}$ & $\begin{array}{c}8.8 \\
\pm 1.22\end{array}$ & $\begin{array}{c}11.5 \\
\pm 0.95\end{array}$ \\
\hline Male live fetuses $(\%)$ & $\begin{array}{r}54 \\
\pm 4\end{array}$ & $\begin{array}{r}53 \\
\pm 6\end{array}$ & $\begin{array}{r}44 \\
\pm 13\end{array}$ & $\begin{array}{r}57 \\
\pm 6\end{array}$ & $\begin{array}{r}52 \\
\pm 5\end{array}$ \\
\hline Mean fetal weight (g) & $\begin{array}{r}4.070 \\
+0.256\end{array}$ & $\begin{array}{r}4.414 \\
\pm 0.094\end{array}$ & $\begin{array}{r}4.428 \\
\pm 0.232\end{array}$ & $\begin{array}{r}3.582 \\
+0.269\end{array}$ & $\begin{array}{r}4.337 \\
\pm 0.113\end{array}$ \\
\hline Mean placental weight $(g)$ & $\begin{array}{r}0.443 \\
\pm 0.014\end{array}$ & $\begin{array}{r}0.444 \\
+0.019\end{array}$ & $\begin{array}{r}0.465 \\
\pm 0.036\end{array}$ & $\begin{array}{r}0.494 \\
\pm 0.025\end{array}$ & $\begin{aligned} & 0.491^{*} \\
\pm & 0.014\end{aligned}$ \\
\hline Fetal weight/placental weight & $\begin{array}{r}9.096 \\
\pm 0.543\end{array}$ & $\begin{array}{r}10.003 \\
\pm 0.421\end{array}$ & $\begin{array}{r}9.639 \\
\pm 0.412\end{array}$ & $\begin{array}{r}7.396 \\
\pm 0.726\end{array}$ & $\begin{array}{r}8.952 \\
\pm 0.412\end{array}$ \\
\hline
\end{tabular}

Values are Means \pm S.E.M.

Significantly different from control value: $* P<0.05 ; * * P<0.01 ; * * * P<0.001$ (unpaired $t$ test).

$\dagger$ Scores for maternal behaviour $2 \mathrm{~min}$ after bleeding: 0 , prostrate with no apparent postural reflexes; 1 , posture correct but no attempt to walk; 2 , would walk if encouraged; 3 , active but dull; 4 , normal.

had been taken for an haematocrit. Generally, rats bled at $2.0 \mathrm{ml} / 100 \mathrm{~g}$ were still dull but were moving around their cages within 15 min of bleeding. Rats bled at $1.0 \mathrm{ml} / 100 \mathrm{~g}$ appeared normal within $15 \mathrm{~min}$ of bleeding. When blood was replaced in the rats of Group 4, some hyperactivity was seen but normal behaviour returned within a few minutes.

There was no apparent effect of blood loss on the number of rats failing to maintain pregnancy between Days 7 and 22, the number of fetuses/litter 
surviving to term (range 8.6 to 11.8 ), or the $\%$ of male fetuses/litter (range 44 to $57 \%$ ).

There was no apparent effect on external malformation rate; only two fetuses were found to be malformed. Mean fetal weights appeared to be unaffected: the lowest weight, $3.582 \mathrm{~g}$ of Group $4 \mathrm{rats}$, was not significantly different from that of the control group, $4.070 \mathrm{~g}$, and weights in the remaining Groups were all slightly higher than that in the control group. Placental weight was $11 \%$ higher in Group $5(P<0.05)$ and Group 4 (not significant) than in the control group. There was no significant difference in fetal weight/placental weight ratios between the experimental and control groups.

Table 2. Effects of maternal blood loss on the maternal haematocrit value throughout gestation in rats

\begin{tabular}{|c|c|c|c|c|c|}
\hline & \multicolumn{5}{|c|}{ Group } \\
\hline & 1 & 2 & 3 & 4 & 5 \\
\hline Blood loss $(\mathrm{m} / / 100 \mathrm{~g})$ & Control & 1 & 1 & $\stackrel{2}{\text { (replaced) }}$ & 2 \\
\hline Day of bleeding & - & 8 & 9 & 9 & 9 \\
\hline No. of measurements & 5 & 7 & 6 & 7 & 4 \\
\hline Day $9 \dagger$ & $\begin{array}{r}39.8 \\
\pm 0.4\end{array}$ & $\begin{array}{c}40.8 \\
\pm 0.7 \ddagger\end{array}$ & $\begin{array}{r}40.8 \\
\pm 0.6\end{array}$ & $\begin{array}{r}36.6 \\
\pm 1.4\end{array}$ & $\begin{array}{r}36 \cdot 2 \\
\pm 2 \cdot 7\end{array}$ \\
\hline Day 10 & $\begin{array}{l}37.0 * * \\
\pm 0.6\end{array}$ & $\begin{array}{l}32 \cdot 0 * * * \\
\pm 0.6 \ddagger\end{array}$ & $\begin{array}{l}29 \cdot 8 * * * \\
\pm 1 \cdot 5\end{array}$ & $\begin{array}{r}35.7 \\
\pm 1.4\end{array}$ & $\begin{array}{l}26.5 * \\
\pm 0.5\end{array}$ \\
\hline Day 15 & $\begin{array}{l}31 \cdot 6 * * * \\
\pm 1 \cdot 4\end{array}$ & $\begin{array}{l}34 \cdot 7 * * * \\
\pm 0 \cdot 6\end{array}$ & $\begin{array}{l}33 \cdot 0 * * * \\
\pm 1 \cdot 3\end{array}$ & $\begin{array}{r}31.8 \\
\pm 1.9\end{array}$ & $\begin{array}{r}32 \cdot 5 \\
\pm 1 \cdot 4\end{array}$ \\
\hline Day 22 & $\begin{array}{l}31 \cdot 0^{* *} \\
\pm 2 \cdot 5\end{array}$ & $\begin{array}{l}33 \cdot 6^{* *} \\
\pm 1 \cdot 7\end{array}$ & $\begin{array}{l}34 \cdot 6 * * \\
\pm 1.5\end{array}$ & $\begin{array}{l}32 \cdot 8^{*} \\
\pm 0 \cdot 9\end{array}$ & $\begin{array}{l}28 \cdot 5^{*} \\
\pm 1 \cdot 2\end{array}$ \\
\hline
\end{tabular}

Values are Means \pm S.E.M.

Significantly different from Day 9 value: $* P<0.05 ; * * P<0.01 ; * * * P<0.001$ (unpaired $t$ test).

$\dagger$ First sample taken from blood withdrawn.

$\ddagger$ Days 8 and 9 , respectively.

There was considerable variation in the mean maternal weight increase (range 32 to $79 \mathrm{~g}$ ) during pregnancy between the five groups. Individual variation between rats was even greater, ranging from -5 to $136 \mathrm{~g}$. There was no indication, however, that weight gained during pregnancy was related to the treatment administered, the number of young surviving/litter or fetal and placental weights, except for the three rats which had the smallest weight change $(-5,-4$ and $+4 \mathrm{~g})$. These rats had litter sizes of 7,13 and 10 , mean fetal weights of 2.929, 2.401 and 2.960 and mean placental weights of 0.589 , 0.407 and 0.400 , respectively.

Haematocrits were measured on Days 9 (Day 8 for Group 2), 10 (Day 9 for Group 2), 15 and 22 in 29 rats to determine the effects of treatment on the normal physiological anaemia of pregnancy (Table 2). Rats in Groups 1 (control) and 4 (bled at $2.00 \mathrm{ml} / 100 \mathrm{~g}$ and replaced) followed a similar pattern, with the developing anaemia of pregnancy being most evident between Days 
10 and 15. Rats in Groups 2 and 3 (bled $1.0 \mathrm{ml} / 100 \mathrm{~g}$ on Days 8 and 9, respectively) clearly had lower haematocrit readings on the day following bleeding, but by Day 15 the haematocrit values had returned to control values and perhaps even exceeded control values by Day 22 (not significant). The greatest anaemia following loss of blood was observed, as expected, in Group 5 (bled $2.0 \mathrm{ml} / 100$ $\mathrm{g}$ ), but even in this group haematocrit values appeared to have recovered by Day 15.

Table 3. Effects of loss of $2.0 \mathrm{ml}$ maternal blood/100 $\mathrm{g}$ body weight on Day 9 of gestation on maternal haematocrit readings and estimated blood volumes

\begin{tabular}{|c|c|c|c|c|c|c|c|}
\hline & \multicolumn{7}{|c|}{ Time after bleeding } \\
\hline & 0 & $7.5 \mathrm{~min}$ & $15 \mathrm{~min}$ & $30 \mathrm{~min}$ & $60 \mathrm{~min}$ & $120 \mathrm{~min}$ & $24 h r$ \\
\hline $\begin{array}{l}\text { Maternal haematocrit } \\
\text { reading** }\end{array}$ & $\begin{array}{r}39.8 \\
\pm 1.3\end{array}$ & $\begin{array}{r}33.6 \\
\pm 0.7\end{array}$ & $\begin{array}{r}33.2 \\
\pm 0.9\end{array}$ & $\begin{array}{r}32.6 \\
\pm 0.8\end{array}$ & $\begin{array}{r}31.4 \\
\pm 0.5\end{array}$ & $\begin{array}{r}30 \cdot 0 \\
\pm 0.3\end{array}$ & $\begin{array}{r}27 \cdot 4 \\
\pm 1.2\end{array}$ \\
\hline $\begin{array}{l}\text { Estimated blood volume } \dagger \\
(\% \text { of original })^{* *}\end{array}$ & $\begin{array}{c}71 \cdot 4 \\
\pm 0\end{array}$ & $\begin{array}{r}84 \cdot 6 \\
\pm 2 \cdot 1\end{array}$ & $\begin{array}{r}85.7 \\
\pm 2.8\end{array}$ & $\begin{array}{r}87.2 \\
\pm 1.7\end{array}$ & $\begin{array}{r}90.5 \\
\pm 2.2\end{array}$ & $\begin{array}{r}94 \cdot 7 \\
\pm 2 \cdot 3\end{array}$ & $\begin{array}{l}104 \cdot 3 \\
\pm 4 \cdot 6\end{array}$ \\
\hline
\end{tabular}

Values are Means \pm S.E.M.

** Effect of time significant $(P<0.01)$, analysis of variance.

$\dagger$ Blood volume indirectly estimated by assuming original blood volume to be $7.0 \mathrm{ml} / 100 \mathrm{~g}$ body weight and at ' $x$ ' min after haemorrhage to be $7-2 \times$ (original haematocrit value/haematocrit value at $\mathrm{x} \mathrm{min}) \mathrm{ml} / 100 \mathrm{~g}$.

The short term effect of loss of $2.0 \mathrm{ml}$ blood $/ 100 \mathrm{~g}$ on maternal haematocrit readings and estimated blood volumes was examined in five 9-day pregnant rats (Table 3). Serial haematocrits were taken at $7 \frac{1}{2}, 15,30,60,120 \mathrm{~min}$ and 24 $\mathrm{hr}$ after bleeding. Blood volumes were estimated indirectly by assuming that the total circulating red blood cell pool was constant after blood loss and that the original blood volume was $7.0 \mathrm{ml} / 100 \mathrm{~g}$. The blood volume immediately after bleeding was then calculated to be $7.0-2.0 \mathrm{ml} / 100 \mathrm{~g}$ or $71.4 \%$ of the original, and the blood volume at ' $x$ ' min after bleeding to be (original haematocrit value/haematocrit value at ' $x$ ' min after bleeding) $\times 71.4 \%$. On this basis the blood volume immediately after bleeding was $29 \%$ lower than normal, from 7.5 to $30 \mathrm{~min}$ it was about $15 \%$ lower and from 60 to $120 \mathrm{~min}$ about $8 \%$ lower. Within $24 \mathrm{hr}$ of the loss of blood, the blood volume had returned to or even exceeded the original value.

\section{DISCUSSION}

It was essential to the present work that fully conscious rats were bled. Conscious rats differ markedly from anaesthetized rats in their physiological response to loss of blood (Bruce, 1973) and total restriction of the uterine circulation appears to have a greater embryopathic effect in conscious rats (Bruce, 1972b). However, cannulation to permit controlled bleeding and haematocrit sampling, had a marked effect on the amount of weight gained during pregnancy. Control rats from our colony normally gain about $90 \mathrm{~g}$, and yet, apart from those rats that were excluded on the basis of having lost $>20 \mathrm{~g}$ after the cannulation 
operation, the amount of maternal weight gained had no apparent effect on the ability of fetuses to survive. Furthermore, except in three rats which gained $<5 \mathrm{~g}$, the amount of maternal weight gain had little effect on fetal weight. In ten rats the mean total weights of the fetuses and placentae were actually $16 \pm 4.2 \mathrm{~g}$ greater than the total increase in maternal weight, and yet litter sizes and fetal weights were well within the normal range. The developing rat conceptus appears to have a considerable ability for obtaining its nutritional requirements, at the expense of its mother if necessary.

The major finding of the present work was that acute maternal loss of blood, up to the level of $2.0 \mathrm{ml} / 100 \mathrm{~g}$ body weight, had no apparent effect on fetal survival, malformation rates or mean fetal weight. Wilson (1953), who bled anaesthetized pregnant rats from a tail vein on 3 successive days found that loss of blood $<1.7 \mathrm{ml} / 100 \mathrm{~g}$ body weight/day also had little effect on pregnancy, although losses of 1.7 to $2.0 \mathrm{ml}$ blood/100 g/day caused a loss of $33 \%$ of the litters. Since Wilson's rats were anaesthetized at the time of bleeding, the rate of bleeding was more protracted and the anaemia resulting from three successive bleeds was more severe, direct comparison between this experiment and that described in the present paper is difficult. Yet both experiments yiclded the unexpected result that the rat embryo can tolerate severe losses of maternal blood.

The effects of a partial restriction of the uterine circulation appear to be considerably less severe than those of a total restriction. There are two possible reasons for this (Brent \& Franklin, 1960). The rat embryo might be able to tolerate, for short periods, a much reduced supply of nutrients or blood gases but not a total lack. On the other hand, if the fetal mortality is due to a build up of toxic waste products, these might well be cleared by a small, greatly reduced uterine blood flow but not by a total cessation of flow. In either case, it is now evident that the susceptibility of the rat embryo to a partial restriction of the uterine blood flow cannot be assessed from experiments involving a total restriction.

Losses of 1 and $2 \mathrm{ml}$ blood/100 $\mathrm{g}$ caused a greater fall in the haematocrit reading than that, presumably due to the normal physiological anaemia of pregnancy (Bond, 1948), observed in the control group. However all haematocrit values had returned to control levels by 6 days after bleeding. From indirect assessments, it appeared that the circulating blood volume had returned to normal levels within $24 \mathrm{hr}$, and thus, the anaemia and hypovolaemia induced by loss of blood never exceeded a duration of 6 days. In those rats subjected to loss of $2.0 \mathrm{ml}$ blood $/ 100 \mathrm{~g}$, placental weights appeared to be higher than in the controls $(P<0.05)$. This finding accords with the report of Beischer $e t$ al. (1968) that, in women, a number of forms of pathological anaemia during pregnancy are associated with enlarged placentae. In the rat, ligation of a uterine artery early in gestation also results in significantly increased placental weights near term (N.W. Bruce, unpublished). These placental weight increases might well represent compensatory hypertrophy in an attempt by the mother to ensure an adequate supply of nutrients and oxygen for her fetuses.

Many experiments have now been conducted on the effects of a shortterm total restriction of uterine blood flow. It is clear that experimental condi- 
tions such as maternal temperature (George et al., 1967; Bruce, 1972a) and state of consciousness (Bruce, 1972b) can affect the results. The time of gestation at which the challenge is administered is also important. At about the time of implantation, Days 4, 5 and 6, restriction of uterine blood flow appears to be particularly lethal to the conceptus; on Days 8 and 9, embryos appear to be more resistant although malformation rates increase (Franklin \& Brent, 1964). Late in gestation, around Day 17, even a partial restriction of the uterine circulation, produced by ligating the uterine artery, markedly increased fetal mortality rates (Wigglesworth, 1964). However, until more comparative information is available on the effects of blood loss on embryonic development in other species and the levels of uterine or maternal placental blood flow in normal and clinically abnormal conditions are better understood, the clinical relevance of restricted uterine blood flow must remain speculative.

\section{ACKNOWLEDGMENTS}

We gratefully acknowledge Miss S. Yap and Mr E. Hunt for their technical assistance. The work was supported by a grant from the National Health and Medical Research Council.

\section{REFERENCES}

Beischer, N.A., Holsman, M. \& Kitchen, W.H. (1968) Relation of various forms of anemia to placental weight. Am. F. Obstet. Gynec. 101, 801-809.

Bond, C.F. (1948) The nature of the anemia of pregnancy in the rat. Endocrinology, 43, 180-186.

Brent, R.L. \& FrankLin, J.B. (1960) Uterine vascular clamping: new procedure for the study of congenital malformations. Science, $\mathcal{N} . r .132,89-91$.

BRUCE, N.W. (1972a) Effects of temporary uterine ischaemia on the rat embryo at different maternal abdominal temperatures. F. Reprod. Fert. 30, 63-69.

BRUCE, N.W. (1972b) Effects of temporary uterine ischaemia on the embryo of the conscious rat. Am. F. Obstet. Gynec. 113, 296-300.

BRUCE, N.W. (1973) Effects of acute maternal hemorrhage on uterine blood flow in the pregnant rat. 7. appl. Physiol. 35, 564-569.

FrankLin, J.B. \& BREnT, R.L. (1964) The effect of uterine vascular clamping on the development of rat embryos three to fourteen days old. F. Morph. 115, 273-290.

George, E.F., FrankLin, J.B. \& Brent, R.L. (1967) Altered embryonic effects of uterine vascular clamping in the pregnant rat by uterine temperature control. Proc. Soc. exp. Biol. Med. 124, 257260.

Wigglesworth, J.S. (1964) Experimental growth retardation in the foetal rat. 7. Path. Bact. 88, 1-13.

WILSON, J.G. (1953) Influence of severe hemorrhagic anemia during pregnancy on development of the offspring in the rat. Proc. Soc. exp. Biol. Med. 84, 66-69.

WiLson, J.G. (1965) Methods for administering agents and detecting malformations in experimental animals. In Teratology, Principles and Techniques, p. 262. Eds. J. G. Wilson and J. Warkany. University of Chicago Press. 